\title{
SOLAR PV ARRAY FED BRUSHLESS DC MOTOR DRIVEN WATER PUMP
}

\author{
A.Arunbalaji \\ Assistant Professor, \\ Department of EEE \\ Vel Tech, Chennai, India,
}

\author{
M.Monishkumar \\ UG scholar, \\ Department of EEE, \\ Vel Tech, Chennai, India
}

\author{
T.Rajakumaran \\ UG scholar, \\ Department of EEE, \\ Vel Tech, Chennai, India
}

\author{
R.Elakkiyan, \\ UG Students, \\ Department of EEE, \\ Vel Tech, Chennai, India,
}

\begin{abstract}
This operation deal with the use of photovoltaic solar energy (SPV) at brushless DC motor driven water pump (BLDC). DC-DC drive converter, employed an transitional power condition unit, act very important role in improving SPV matrix competence and BLDC motor soft start to appropriate control. BLDC motor speed control is implemented to PWM control of Voltage Source Inverter employing DC link voltage regulator. No extra control or current sense constituent is necessary to speed control. The performance of established pumping system determined to analyze its several presentations via simulation study depend on MATLAB / simulink
\end{abstract}

Keywords - BLDC motor, Boost converter, PWM, Soft starting ,Solar PV, Speed control, VSI.

\section{INTRODUCTION}

The Pumping water has turn into gorgeous application of photovoltaic solar energy, mainly at distant rural areas, here power transmission is nearly not possible or extravagant if probable (Kumar and Singh, 2017). Normally, DC-DC converter is used to track the maximal power point of an SPV matrix. DC-DC step-down converter (Mapurunga Caracas, De Carvalho Farias, Moreira Teixeira and De Souza Ribeiro, 2014) is employed to permanent magnet DC motor driven centrifugal pump (PMDC). PMDC motor, though it bypasses power conversion stages, i.e. voltage source inverter, unhappily less competence, large preservation cost needs recurrent preservation (Roberts, 1973). On contrary, buck converter essentially requires a ripple filter input, outcomes at higher cost and size, therefore it is not modified.

These operations, DC-DC to MPPT boost converter from PV array are used. Causes to opting for these converter is inherent property of minimal probable switch stress, large change competence due to fewer components, better switch operation as well as removal of input ripple filter as input inductor itself it react ripple filter (Potok, 1980). Apart from three classic DC-DC converter, viz. buck, boost and buckboost converter, entire another methodologies evolved

The authors (Singh and Bist, 2015) consists great number of components that outcomes at deterioration of competence, higher cost, weight as well as size. Additionally, this converter, consists of classic buck-boost converter, experience increased stress on power devices as well as poor switch operation. These problems give confidence using an impulse converter to desired task.

Induction motor is broadly used machine with water pump based on robustness, less cost, great competence, ease of use at local markets as well as less maintenance cost compared with DC motor (Roberts, 1973). Therefore, these motors undergoes as complex control requirement as well as overheat issues, therefore it is not modified (Singh and Bist, 2015). Thus, a brushless DC (BLDC)motor, possess a great competence and dependability to induction motor, less EMI as well as noise, no maintenance (Kumar and Singh, 2017; Ali, 2016) used at established water pump system.

A grouping of boost converter as well as BLDC motor is previously accounted ("A Cost Effective PFC Bridgeless Buck Boost Converter-Fed BLDC Motor Drive", 2018) to pump water, yet closed-loop control employed with control BLDC motor speed that need extra current sense elements as well as complex control method. In established system, as BLDC motor speed ordered to VSI pulse width modulation employing DC link voltage regulator, no extra current sense element or control method is employed. BLDC motor drive no current sensor as well as closed loop speed control to SPV matrix feed water pump account (Kumar and Singh, 2017; 8$10]$, yet this method employ DC-DC converters like boost converter (Odeh, Yohanis and Norton, 2006), Cuk converter, Luo converter (Singh and Kumar, 2016) as well as canonic switch cell converter (Singh and Kumar, 2016; Mythili et al., 2020) that have disadvantages of misuse of switch, high stress on its power devices as well as great number of immediate element (Potok, 1980; Transpire online, 2019).

As account at (Taghvaee, Radzi, Moosavain, Hizam and Hamiruce Marhaban, 2013), boost converter, which has a limited MPPT region, reason design restriction in SPV matrix. However, SPV matrix chosen to guarantee as MPPT is guaranteed despite of weather conditions. In addition, appropriate selection of SPV matrix as well as BLDC motor guarantee optimal design of boost converter. Operation of continuous conduction mode (CCM) is modified to operation of boost converter to obtain the decreased voltage in semiconductor device as well as components. BLDC motor, 
initial current is restricted as well as soft initial achieved to appropriate SPV control matrix via MPP operation.

Offering ease, compactness as well as cost-efficiency, established pumping system is intended to work effectively still 20\% standard solar irradiance. System is intended, modeled as well as its presentation is evaluated at MATLAB / simulink environment. Several initial, steady-state and dynamic characteristics are analyzed, taking into account the practical operation conditions that determines their appropriateness to water pump

\section{CONFIGURATION OF PROPOSEDSYSTEM}

Figure 1 displays a full schematic of BLDC motor driven water pump fed to PV array. It comprises SPV matrix, DC-DC converter, VSI motor, BLDC as well as water pump. An increment conductance MPPT (INC) technique is implemented to perform competence of photovoltaic matrix via operation of boost converter. On contrary, BLDC motor speed control as well as electronic switch is done using the PWM control of VSI. A built-in encoder, rise on BLDC motor itself, gives three Hall signals after rotor location that is converted with six pulses. Below sections complicated design as well as control topologies of established system

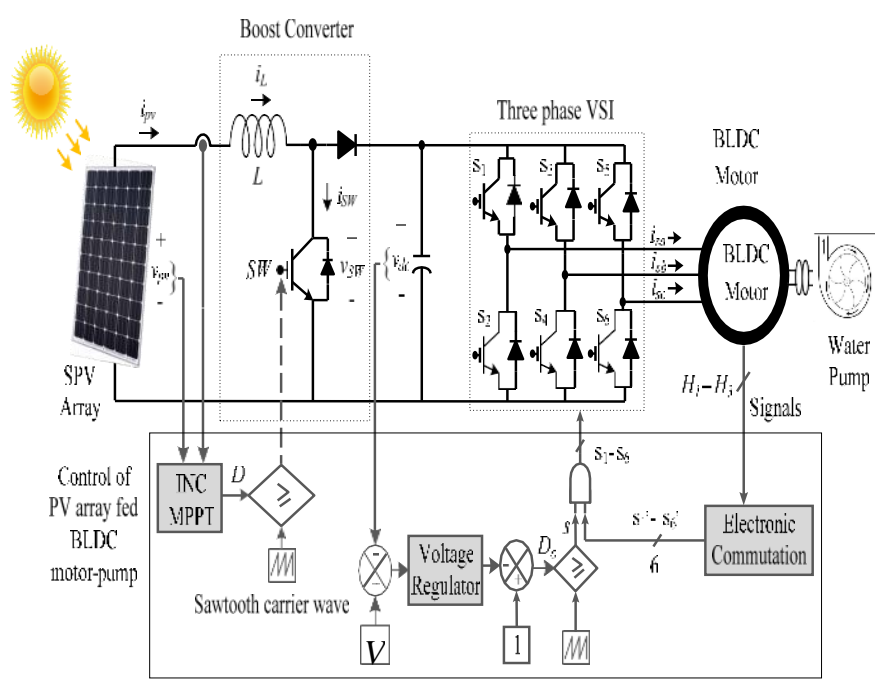

Fig.1 Configuration of photovoltaic array fed to BLDC motor pump.

\section{PROPOSED SYSTEMDESIGN}

Design of established water pump system is depend on assortment of BLDC pump and motor. BLDC motor to nominal power of $1.8 \mathrm{~kW}$ choosen, as point to at Table I, and another method, viz. The photovoltaic array, DC-DC Boost converter as well as water pump is intended consequently. Opinion of several parameters is complicated at below sections.

\section{A. Design of SPV Array}

The $2.24 \mathrm{~kW}$ maximal power SPV array is chosen with BLDC motor power - $1.8 \mathrm{~kW}$ nominal power pump. SPV excess power set is necessary with recompense loss of converters as well as motor pump. To approximate as another parameters, SPV matrix voltage is initial examined due to BLDC motor rated DC voltage as well as boost converter optimal design. It chosen like, which optimal working ratio in MPP is minimal possible value that outcomes at good use of switch, decreased voltage as well as current voltage at power devices, decreased current rate of inductor. An HB-1280 photovoltaic module, contrived to HBL Power System Ltd. ("Simulation Of Inverter For Prototype Module Of Solar Photovoltaic (Pv) System", 2018) to maximal power as $80 \mathrm{~W}$ in normal insolation level $1000 \mathrm{~W} / \mathrm{m} 2$ is examined with SPV array design of necessary capacitance. Table II shows assessment of parameter.

\section{B. Design of Boost DC-DC Converter}

SPV matrix voltage MPP, $v_{p v}=V_{m p p}=238 \mathrm{~V}$ is increased with VSI voltage DC bus, $V_{d c}=310 \mathrm{~V}$. These present minimal working ratio, $D$, which outcomes at advantage mention at section earlier. Table III summarize estimate of inductance, $L$ (Potok, 1980) as well as capacitance, $C$ (Kumar and Singh, 2017), here $f_{s w}$ denotes switch frequency of boost converter; $I_{L}$ represents current of inductor; $\Delta I_{L}$ represents ripple contents at current inductance;

Table 1. BLDC Motor Specification

\begin{tabular}{|c|c|}
\hline \multicolumn{2}{|c|}{ Solar Photovoltaic Module } \\
\hline Cell & 36 \\
\hline Voltage module & $21 \mathrm{~V}$ \\
\hline Current module & $5.6 \mathrm{~A}$ \\
\hline MPP voltage module, $V_{m}$ & $17 \mathrm{~V}$ \\
\hline MPP current module, $I_{m}$ & $4.75 \mathrm{~A}$ \\
\hline \multicolumn{2}{|c|}{ Solar Photovoltaic array } \\
\hline Voltage MPP, $V_{m p p}=v_{p v}$ & $238 \mathrm{~V}$ \\
\hline MPP power, $P_{m p p}=p_{p v}$ & $2240 \mathrm{~W}$ \\
\hline MPP current, $I_{m p p}=i_{p v}$ & $P_{m p p} / V_{m p p}=2240 / 238=9.4 \mathrm{~A}$ \\
\hline Modules number at series, $N_{s}$ & $V_{m p p} / V_{m}=238 / 17=14$ \\
\hline Modules number at parallel, $N_{p}$ & $I_{m p p} / I_{m}=9.4 / 4.75=1.98 \approx 2$ \\
\hline
\end{tabular}

* The VSI DC bus includes sixth harmonic component of VSI output voltage

In table $1 \Delta V_{d c}$ denotes ripple content at capacitance voltage; $I_{d c}$ is average current flow via VSI DC bus; $f$ and $\omega$ denotes BLDC motor input voltage frequency at $\mathrm{Hz}$ and $\mathrm{rad} / \mathrm{sec}$. correspondingly. BLDC motor poles are mentioned to $P$, and BLDC motor speed is mentioned to $N_{r}$. Values of converter parameters is chosen like established system implements adequately even in bad weather condition. 
Table 2. SPV array design

\begin{tabular}{|c|c|}
\hline Power, $P$ & $1.8 \mathrm{~kW}$ \\
\hline Speed, $N_{r}$ & $3000 \mathrm{rpm}$ \\
\hline DC voltage, $V_{d c}$ & $310 \mathrm{~V}$ \\
\hline Poles, $P$ & 4 \\
\hline Inertia, $J$ & $3.5 \mathrm{~kg} . \mathrm{cm} 2$ \\
\hline Current, $I_{s}$ & $5.64 \mathrm{~A}$ \\
\hline Voltage constant, $K_{e}$ & $78 \mathrm{~V} / \mathrm{krpm}$ \\
\hline Torque constant, $K_{t}$ & $0.74 \mathrm{Nm} / \mathrm{A}$ \\
\hline Resistance phase, $R_{s}$ & $2.3 \Omega$ \\
\hline Inductance phase, $L_{s}$ & $7.68 \mathrm{mH}$ \\
\hline
\end{tabular}

Table 3 Boost DC-DC converter design

\begin{tabular}{|c|c|c|c|c|}
\hline $\begin{array}{l}\text { Para- } \\
\text { meter }\end{array}$ & Expression & Data & Value & $\begin{array}{c}\text { Selected } \\
\text { value }\end{array}$ \\
\hline$D$ & $\frac{V_{d c} \square v_{p v}}{V_{d c}}$ & $\begin{array}{l}v_{p v}=238 \mathrm{~V} \\
V_{p v}=310 \mathrm{~V}\end{array}$ & 0.23 & 0.23 \\
\hline$L$ & $\begin{array}{c}I_{L}=N_{p} * I_{m} \\
L \square{ }^{*} v_{p v} \\
\quad f_{s w} \square I_{L}\end{array}$ & $\begin{array}{c}D=0.23 \\
v_{p v}=238 \mathrm{~V} \\
f_{s w}=20 \mathrm{kHz} \\
N_{p}=2 \\
I_{m}=4.75 \mathrm{~A} \\
\Delta I_{L}=10 \% \text { of } I_{L}\end{array}$ & $\begin{array}{l}2.88 \\
\mathrm{mH}\end{array}$ & $3 \mathrm{mH}$ \\
\hline$C$ & $\begin{array}{c}\square 2^{*} \square * f \square \\
2^{*} \square * N_{r} * P \\
120 \\
I_{d c}=P_{m p p} / V_{d c} \\
{ }^{*} C \square \quad I_{d c} \\
6^{*} \square * \quad \square V_{d c}\end{array}$ & $\begin{array}{c}P=4 \\
N_{r}=3000 \mathrm{rpm} \\
V_{d c}=310 \mathrm{~V} \\
P_{m p p}=2240 \mathrm{~W} \\
\Delta V_{d c}=2 \% \text { of } V_{d c}\end{array}$ & $309 \mu \mathrm{F}$ & $500 \mu \mathrm{F}$ \\
\hline
\end{tabular}

\section{Design of Pump}

Water pump is intended based on power speed behaviors (Kumar and Singh, 2017; Jones, 2013) such as,

\section{Brushless DC Motor Electronic Commutation}

VSI that powers brushless DC motor is switched at forecast sequence to implement known as electronic switch (Kumar and Singh, 2017; Ali, 2016). The method of changing three Hall signals at six switch signal, $\mathrm{s}_{1},-\mathrm{s}_{6}$, Three Hall signal is originated to encoder, mount on shaft, due to its location rotor. Two switches of conduction in time outcomes on decreased loss of conduction.

\section{E. Speed Control of Brushless DC Motor-Pump}

BLDC motor pump speed control is proficient to VSI PWM switching though regulate the voltage bus DC. Fig. 1 displays, reference as well as sense voltage bus DC, $V_{d c} *$ and $v_{d c}$ correspondingly, contrast and accepted error via voltage regulator that denotes PI controller. In addition, value of output voltage regulator contrasted to maximal probable value of working ratio, i.e. 1 to get last working ratio, Do. Comparing Do as well as great frequency carrier wave outcome at basics as well as need voltage sensor in DC link, outcomes at less difficulty, cost, size.

\section{Simulated Results And Performance AnAlysis}

In established water pump system is replicated at MATLAB surrounding by determine initial, stable as well as dynamic characteristics subject with rapid variant of climatic condition. These presentations, suggested at Figs. 2-7, consist of presentation of solar photovoltaic generator, DC-DC converter as well as brushless DC motor pump detailed at below sections.

\section{PRoposed System CONTROL}

The control methods employed in several method of established water pump system split into below three part.

\section{A. Solar PV Array MPPT}

To improve the competence of an SPV matrix, MPPT is obligatory based on changeable weather conditions. Established system becomes accustomed INC ways of MPPT method (Mapurunga Caracas, De Carvalho Farias, Moreira Teixeira and De Souza Ribeiro, 2014; e Brito, Galotto, Sampaio, e Melo and Canesin, 2013). These methods are least responsive system dynamic as well as noise. Direct service ratio control employed due to provide better stability as well as ease individuality. At first working ratio is fixing with zero at see of smooth beginning engine. Similarly, size of disturbance is 0.001 to obtain a decreased oscillation around optimum operating point.

\section{B. System at $1000 \mathrm{~W} / \mathrm{m}^{2}$}

At beginning behavior as well as stable state of several index of photovoltaic solar panels, booster DC-DC converter as well as brushless DC motor-pump is suggested at Figs. 2-4 correspondingly. Fig. 2, SPV matrix MPP is correctly track; therefore SPV matrix working in $2240 \mathrm{~W}$. Boost converter working at CCM as well as VSI DC bus voltage synchronized to $310 \mathrm{~V}$ displays at Fig. 3. Maximum voltage at switch denotes $310 \mathrm{~V}$. Likewise, maximum current voltage at switch seen 9.5 A. Fig. 4 shows as current. The motor is bounded with range allowed in start-up as well as motor is working in its rate value. Speed $3000 \mathrm{rpm}$, water pump at complete capacitance.

\section{Dynamic Performance of Proposed System}

To determine dynamic characteristics of established water pump system, irradiance maximized as $200 \mathrm{~W} / \mathrm{m}^{2}$. 
International Journal of Engineering Applied Sciences and Technology, 2020

Vol. 5, Issue 1, ISSN No. 2455-2143, Pages 623-628

Published Online May 2020 in IJEAST (http://www.ijeast.com)

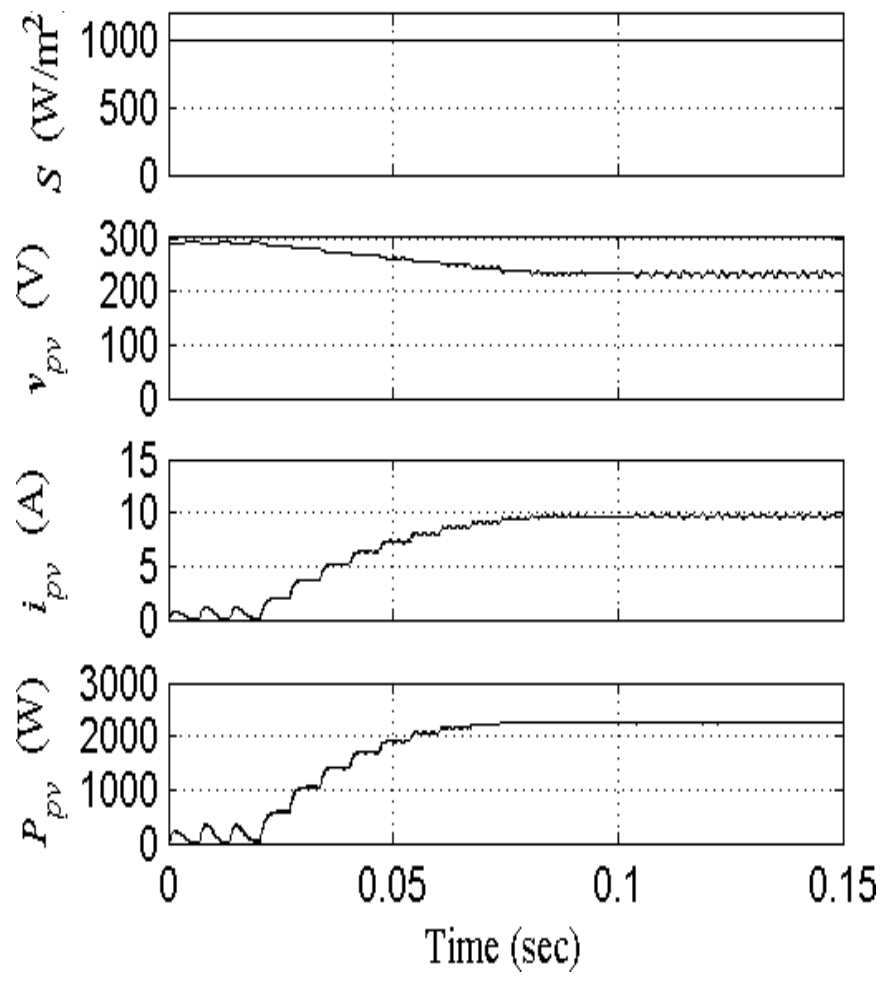

Fig.2 Starting and stable state presentation of solar photovoltaic array
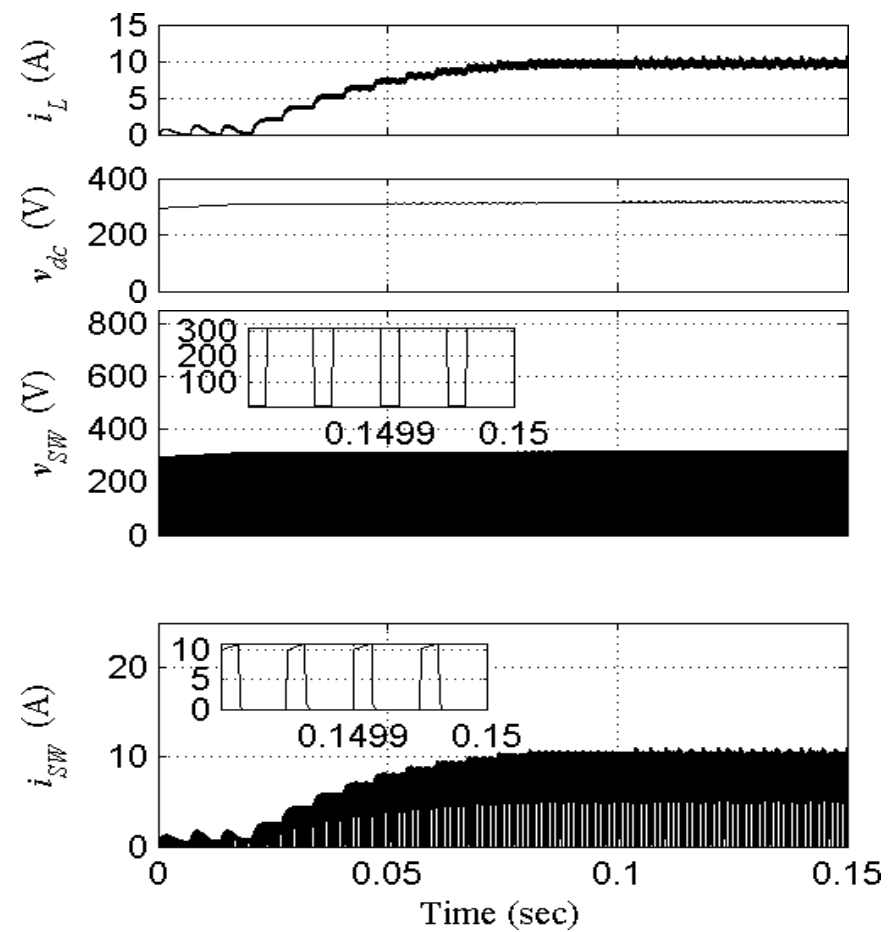

Fig.3 DC-DC boost converter startup and stable state presentation
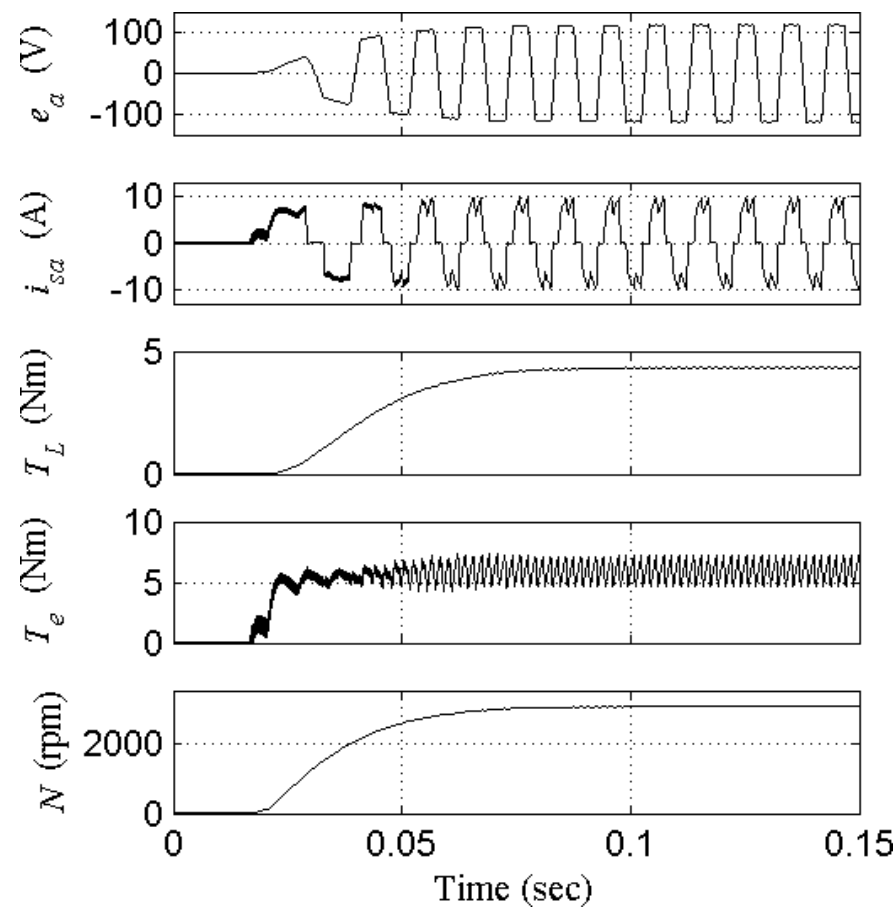

Fig.4 Stable startup and performance of brushless DC motor pump
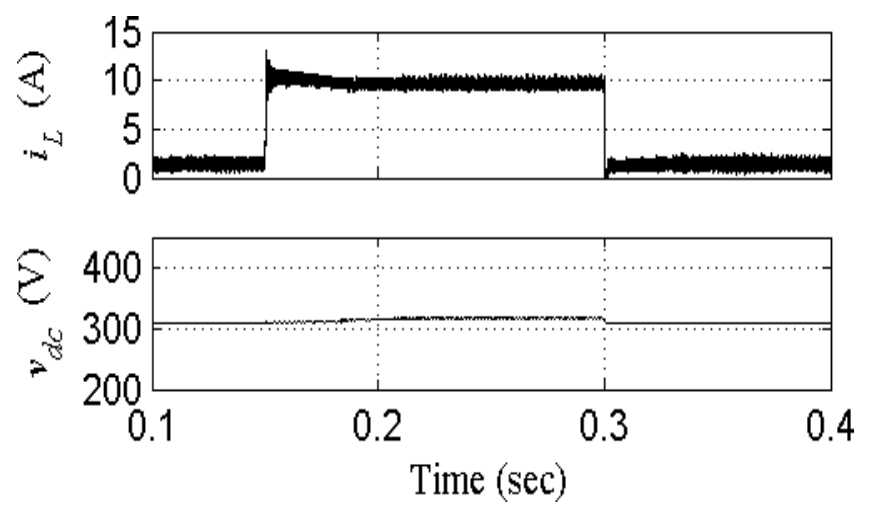

Fig.5 Dynamic presentation of solar photovoltaic array
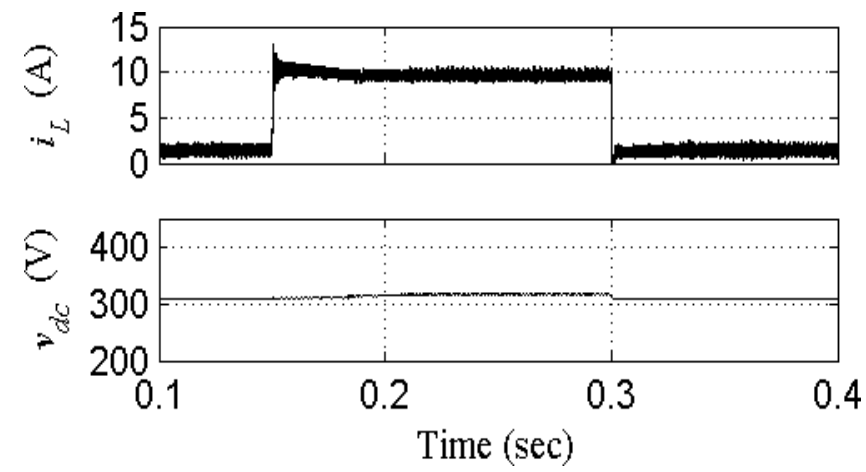

Fig.6 DC-DC boost converter dynamic performance 

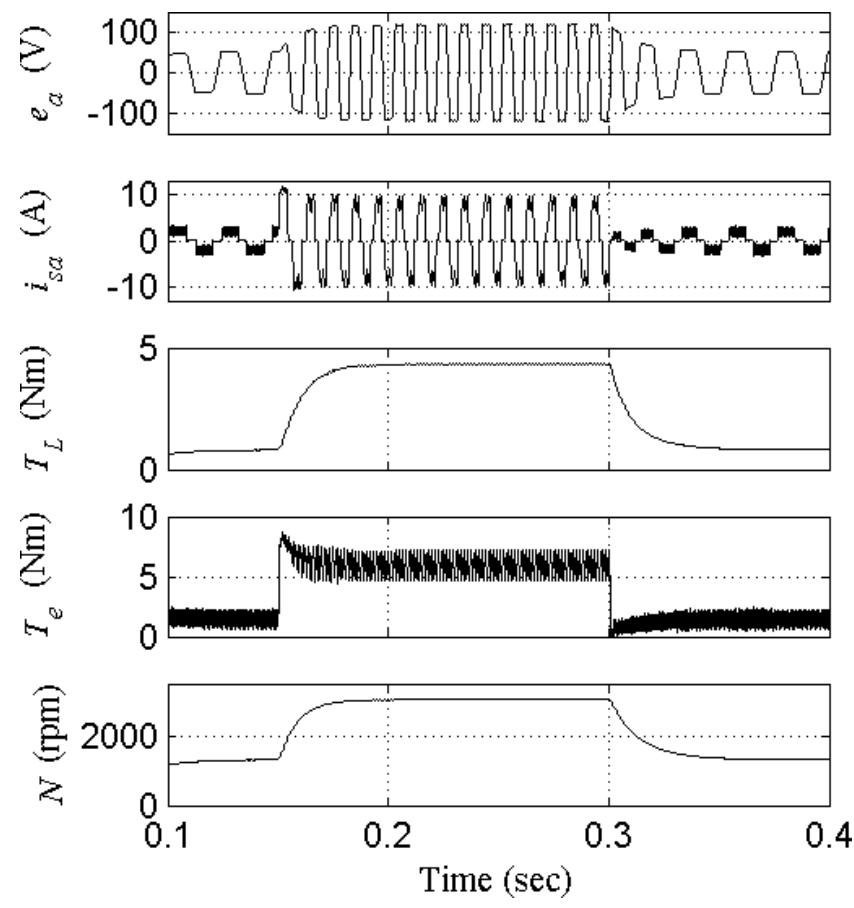

Fig.7 Dynamic presentation of brushless DC motor - pump

\section{CONCLUSIONS}

SPV booster converter-depend on BLDC motor-driven water pump is established as well as appropriateness is determined to evaluate its several presentation indices using the MATLAB-depend on imitation study. Simple, well-organized as well as inexpensive technique to BLDC motor speed control has been introduced that offered the complete removal of current sense element. Appropriate selection of SPV matrix is boost converter able to track MPP regardless of weather conditions. Optimal design of boost converter is suggested. Safe start of brushless DC motor is attained no extra control. As preferred presentation of established system, still $20 \%$ of normal solar irradiance, is necessary its appropriateness to pumping water depend on photovoltaic solar energy.

\section{REFERENCE}

[1] Kumar, R., and Singh, B. (2017). Solar PV powered BLDC motor drive for water pumping using Cuk converter. IET Electric Power Applications, 11(2), 222-232.

[2] Mapurunga Caracas, J., De Carvalho Farias, G., Moreira Teixeira, L., and De Souza Ribeiro, L. (2014). Implementation of a High-Efficiency, HighLifetime, and Low-Cost Converter for an Autonomous Photovoltaic Water Pumping System. IEEE Transactions On Industry Applications, 50(1), 631-641.
[3] Roberts, M. (1973). Sykes, Peter. A guidebook to mechanism in organic chemistry (3rd ed.). New York: John Wiley and Sons, Inc., 1970 (301 pages), \$5.50. Science Education, 57(1), 100-100.

[4] Potok, M. (1980). Microwave Devices and Circuits. Electronics And Power, 26(7), 592

[5] Singh, B., and Bist, V. (2015). A BL-CSC ConverterFed BLDC Motor Drive With Power Factor Correction. IEEE Transactions On Industrial Electronics, 62(1), 172-183.

[6] Ali, U. (2016). Z-source DC-DC Converter with Fuzzy Logic MPPT Control for Photovoltaic Applications. Energy Procedia, 90, 163-170.

[7] A Cost Effective PFC Bridgeless Buck Boost Converter-Fed BLDC Motor Drive. (2018). International Journal Of Recent Trends In Engineering And Research, 174-179.

[8] Odeh, I., Yohanis, Y., and Norton, B. (2006). Influence of pumping head, insolation and PV array size on PV water pumping system performance. Solar Energy, 80(1), 51-64.

[9] Singh, B., and Kumar, R. (2016). Solar photovoltaic array fed water pump driven by brushless DC motor using Landsman converter. IET Renewable Power Generation, 10(4), 474-484.

[10] Singh, B., and Kumar, R. (2016). Simple brushless DC motor drive for solar photovoltaic array fed water pumping system. IET Power Electronics, 9(7), 14871495.

[11] Taghvaee, M., Radzi, M., Moosavain, S., Hizam, H., and Hamiruce Marhaban, M. (2013). A current and future study on non-isolated DC-DC converters for photovoltaic applications. Renewable And Sustainable Energy Reviews, 17, 216-227.

[12] Simulation Of Inverter For Prototype Module Of Solar Photovoltaic (Pv) System. (2018). International Journal Of Recent Trends In Engineering And Research, 3(12), 228-234.

[13] Jones, W. (2013). Motor Selection Made Easy: Choosing the Right Motor for Centrifugal Pump Applications. IEEE Industry Applications Magazine, 19(6), 36-45.

[14] de Brito, M., Galotto, L., Sampaio, L., e Melo, G., and Canesin, C. (2013). Evaluation of the Main MPPT Techniques for Photovoltaic Applications. IEEE Transactions On Industrial Electronics, 60(3), 1156-1167.

[15] A New Seagull Optimization Algorithm to Solve Numerical Optimization Problems, Transpire online (2019). Available at: https://transpireonline.blog/2019/08/30/a-new- 
International Journal of Engineering Applied Sciences and Technology, 2020

Vol. 5, Issue 1, ISSN No. 2455-2143, Pages 623-628

Published Online May 2020 in IJEAST (http://www.ijeast.com)

seagull-optimization-algorithm-to-solve-numericaloptimization-problems/. [Accessed on: 10 Jan 2020]

[16] Mythili, S., Thiyagarajah, K., Rajesh, P., and Shajin F. H. (2020). Ideal position and size selection of unified power flow controllers (UPFCs) to upgrade the dynamic stability of systems: An antlion optimiser and invasive weed optimisation Algorithm. HKIE Transactions. $27.25-37$. 10.33430/V27N1THIE-2018-0024. 